\title{
Bacteriocin-Producing Enterococci from Rabbit Meat
}

\author{
Renáta Szabóová ${ }^{*}$, Andrea Lauková ${ }^{1}$, Monika Pogány Simonová ${ }^{1}$, Viola Strompfová ${ }^{1}$ and Lubica Chrastinová ${ }^{2}$ \\ ${ }^{1}$ Institute of Animal Physiology Slovak Academy of Sciences, Šoltésovej 4-6, 04001 Košice, Slovak Republic \\ ${ }^{2}$ Animal Production Research Centre, Institute of Nutrition, Hlohovecká 2, \\ 95141 Lužianky-Nitra, Slovak Republic \\ E.mail: szaboova@saske.sk
}

Received $15^{\text {th }}$ July 2011; Received in revised form $8^{\text {th }}$ February 2012; Accepted $13^{\text {th }}$ April 2012

\begin{abstract}
Aims: Enterococci are lactic acid bacteria belonging to the division Firmicutes. They occur in different ecosystems, rabbits including. Enterococci can possess probiotic properties and produce antimicrobial substances-bacteriocins. Rabbit meat as nutritionally healthy food offers novel source to study bacteriocin-producing and/or probiotic enterococci. Methology and result: Enterococci were detected from rabbit meat samples (42). Most of the isolates were allotted to the species Enterococcus faecium by PCR method. The isolates have possessed the structural genes for enterocins A, $\mathrm{P}, \mathrm{B}$ production. The inhibitory substances produced by the isolated enterococci inhibited the growth of 12 indicators. Of 34 isolates, 15 strains have shown the antimicrobial activity against L. monocytogenes CCM 4699, 12 strains against $S$. aureus 3A3, 10 strains against $S$. aureus $5 \mathrm{~A} 2$ as well as Salmonella enterica serovar Enteritidis PT4. Moreover, enterococci have tolerated $5 \%$ bile, low pH; they have produced lactid acid in the amount from $0.740 \pm 0.091$ to $1.720 \pm$ $0.095 \mathrm{mmol} / \mathrm{l}$. The isolates were mostly sensitive to antibiotics.

Conclusion, significance and impact of study: Bacteriocin-producing strain E. faecium M3a has been selected for more detail characterization of its bacteriocin and probiotic properties with the aim for its further application as an additive.
\end{abstract}

Keywords: bacteriocin, probiotic bacteria, antimicrobial effect

\section{INTRODUCTION}

Enterococci are Gram-positive, facultative anaerobic, catalase-negative lactic acid bacteria (LAB) taxonomically allotted to the division Firmicutes, the class Bacilli, the order Lactobacillales, the family Enterococcacae and the genus Enterococcus (Bergeys Manual of Systematic Bacteriology, 2009). They have been isolated from different ecosystems, rabbit meat including (Devriese et al., 1993; Aymerich et al., 1996; Franz et al., 2007; Szabóová, 2011). In general, enterococci are studied for their probiotic and bacteriocin-producing properties to have beneficial effect e.g. as novel additives in animal nutrition. Rabbit meat is considered to be one of the healthiest meats because of its easily digestion and dietetic properties, e.g. high values of proteins (20-21\%), unsaturated fatty acids, potassium, phosphorus, magnesium and low fat, cholesterol, sodium contents (Dalle Zotte, 2002).

The occurrence of enterococci in rabbit meat could be mostly originated from the environment in the time of slaughtering. There, the majority isolates have been allotted to the species Enterococcus faecium (Szaboová, 2011). The ability of $L A B$ to produce natural antimicrobial substances - organic acids, diacetyl, hydrogen peroxide and bacteriocins has been well known (Franz et al., 2007). Bacteriocins produced by enterococcci, mostly enterocins are of considerable interest because they have provided an inhibitory activity against spoilage microbiota such as Listeria monocytogenes, Staphylococcus aureus, Escherichia coli, Salmonella Enteritidis (Lauková and Czikková, 1998, 1999; Franz et al., 2007; Levkut et al., 2009). Effect of several bacteriocins produced by enterococci, mainly those produced by the strians of the species Enterococcus faecium of different origin have been previously reported and they have been more frequently applied as protective cultures or feed supplements (Strompfová et al., 2003, 2006; Audisio et al. 1999; Szabóová et al., 2008; Pogány Simonová et al., 2009, Levkut et al., 2011). Taking into the principal interest the health property of rabbit meat, the novelty point of this basic research has been focused on enterococci isolated from rabbit meat to study their bacteriocin activity and some probiotic properties (which has not been studied yet).

\section{MATERIALS AND METHODS}

\section{Isolation and Identification of Bacteria}

Enterococci were isolated from rabbit back limb (musculus biceps femoris) of 42 rabbits (males, Hyplus breed at the farm of Animal Production Research Centre, Nitra, Slovakia). Animal handling and sampling was provided according to the guidelines stated in the Guide for the 
Care and Use of Laboratory Animals accepted by Slovak Governmental Veterinary Institution and Ethic Commission. The samples $(10 \mathrm{~g})$ were treated by the standard microbiological method according to ISO using appropriate dilutions in Buffered Peptone Water $(90 \mathrm{ml}$, Biomark, India). The appropriate dilutions were plated onto Kanamycin Esculin Agar (Biomark, India), incubated at $37^{\circ} \mathrm{C}$ for $24 \mathrm{~h}$ in partially $\mathrm{CO} 2 /$ air atmosphere.

The counts of enterococci were expressed in the colony forming units (cfu) and quoted as means \pm SD. Colonies of enterococci (34) were randomly picked up, checked for purity and maintained on Kanamycin Esculin Agar. The isolates were genotyped using the polymerase chain reaction-PCR method (Techgene, KRD ThermocyclerTechne, The United Kingdom) followed by the agarose electrophoresis in $0.8 \%$ agarose gels (Sigma, Germany) buffered with 1xTAE (Merck) containing $1 \mu \mathrm{g} / \mathrm{ml}$ of ethidium bromide (Sigma). The molecular mass standard (Promega, USA) was used according to the manufacturers' instructions. DNA (template) from each strain was isolated by the rapid alkaline lysis method (Baele et al. 2000). Ten microlitres of the template was added to $39.5 \mu \mathrm{l}$ of the reagent mixture which contained $0.5 \mu \mathrm{M}$ each of the primers; $0.2 \mathrm{mM}$ each of the deoxynucleotides (dATP, dTTP, dCTP, dGTP) - dNTPs (Invitrogen); $2.5 \mathrm{mM}$ of $\mathrm{MgCl} 2$ (Invitrogen); 10xPCR buffer (Invitrogen); $1.25 \mathrm{U}$ of Taq polymerase (Invitrogen) and $\mathrm{H} 20$ to the total volume of $50 \mu \mathrm{l}$.

The sequences of the primer pairs prepared according to Woodford et al. (1997) and used for DNA amplification of Enterococcus faecium were as follows: 5' GCAAGCTTCTTAGAGA-3' and 5'-CATCGTGTAAGCTA ACTTC-3' (Invitrogen). The sequences of the primer pairs for DNA amplification of Enterococcus faecalis were $5^{\prime}$ ATCAAGTACAGTTAGTCTT-3' and 5'-ACGATTCAAAGC TAACTG-3' (Invitrogen). The amplification protocol was as follows: initial denaturation at $95{ }^{\circ} \mathrm{C}$ for $2 \mathrm{~min}, 40$ cycles of $95^{\circ} \mathrm{C}$ for $1 \mathrm{~min}, 55^{\circ} \mathrm{C}$ for $1 \mathrm{~min}, 72^{\circ} \mathrm{C}$ for $1 \mathrm{~min}$, $72 \stackrel{\circ}{\circ}$ for 10 min. E. faecium EK13 (CCM 7419, our isolate and E. faecalis CCM 4224 (Czech Culture Collection, Brno, Czech Republic) were used as positive controls.

\section{Detection of The Structural Genes for Bacteriocin Production}

The strains were tested to possess the following enterocins (Ent) genes: Ent A, B, P and L50B. Enterocins mentioned, have been detected most frequently in different enterococcal strains (Strompfová and Lauková, 2007, 2009; Lauková et al., 2008a, 2008b).DNA was extracted by rapid alkaline lysis method (Baele et al., 2000). Template $(2 \mu \mathrm{l})$ was added to $8.75 \mu \mathrm{l}$ of the reagent mixture which contained $0.5 \mu \mathrm{l}$ of each primer, $1 \mu \mathrm{l}$ of $(10$ $\mathrm{nmol} / \mathrm{L})$ dNTPs (Invitrogen), $1.5 \mu \mathrm{l}$ of $(5 \mathrm{mmol} / \mathrm{L}) \mathrm{MgCl}_{2}$ (Invitrogen), $5 \mu$ l of 10x reaction buffer (Invitrogen), $0.25 \mu \mathrm{l}$ of $1 \mathrm{U}$ Taq polymerase (Invitrogen) and water to a total volume of $50 \mu \mathrm{l}$. The sequences of the primers pairs used for PCR amplification of the enterocin structural genes -
Ent A, P, L50B and B are summarized in Table 1. The reaction conditions for Ent $A$ detection included 5 min denaturation at $95{ }^{\circ} \mathrm{C}$, followed by 30 cycles of $30 \mathrm{~s}$ at 95 ${ }^{\circ} \mathrm{C}, 30 \mathrm{~s}$ at $58^{\circ} \mathrm{C}, 30 \mathrm{~s}$ at $72{ }^{\circ} \mathrm{C}$; then $5 \mathrm{~min}$ at $72{ }^{\circ} \mathrm{C}$ and a cool down to $4{ }^{\circ} \mathrm{C}$. For Ent $\mathrm{P}, \mathrm{L} 50 \mathrm{~B}$ and $\mathrm{B}$, the temperature $56{ }^{\circ} \mathrm{C}$ instead of $58{ }^{\circ} \mathrm{C}$ was used as the annealing temperature. PCR products were visualised by $2 \%$ agarose electrophoresis, containing $1 \mu \mathrm{g}$ of ethidium bromide. Positive control strains were: E. faecium EK13 (Mareková et al., 2003) for Ent A; E. faecium AL41 (Lauková et al., 2003) for Ent P; E. faecium L50 (Cintas et al., 1998) for Ent L50B, B.

\section{Bacteriocin Activity}

Bacteriocin activity was tested by the qualitative agardiffusion technique according to Skalka et al. (1983) using $\mathrm{BHI}$ agar. The target of the indicator bacteria used have represented rabbits isolates as well as isolates depended on the phylogenetic relation with enterococci e.g. listeriae. The principal indicator strain was Enterococcus avium EA5 (our isolate from faeces of piglet), E. faecium CCM 7420 (our isolate from rabbits faeces deponed to Czech Culture Collection of Microorganisms in Brno-CCM, Czech Republic), Listeria innocua LMG 13568 (Collection of Microorganisms at University of Ghent, Belgium), $L$. monocytogenes CCM 4699 (clinical isolate, CCM), $L$. monocytogenes 2024, L. monocytogenes 7223, L. monocytogenes 7562 (isolates from food, Veterinary Institute, Olomouc, Czech Republic), Salmonella enterica serovar Enteritidis PT4 (Dr. Šišák, Brno, Czech Republic), Staphylococcus aureus SA5 (our isolate from mastitis milk), $S$. aureus 3A2, 3A3, 5A2 (our isolates from rabbits faeces). The inhibitory activity was expressed in $\mathrm{mm}$.

\section{Resistance to Bile, Low pH, Lactic Acid Production, Sensitivity/Resistance to Antimicrobials}

The resistance to bile was tested according to Gilliland and Walker (1990). Brain Heart Infusion broth (BHI, Becton and Dickinson, USA) was prepared by the addition of $5 \%(\mathrm{w} / \mathrm{v})$ oxgall (Becton and Dickinson). The volume $50 \mu \mathrm{l}$ of an $18 \mathrm{~h}$ culture of each strain was added to $5 \mathrm{ml}$ of $\mathrm{BHI}$ broth with oxgall. After incubation at $37^{\circ} \mathrm{C}$ for $24 \mathrm{~h}$, the bacterial growth of strains was measured using a spectrophotometer (Specol 11, Jena, Germany) at 600 $\mathrm{nm}$. Viable cells were estimated at $0 \mathrm{~h}$ and after $24 \mathrm{~h}$ of the incubation on M-Enterococcus agar (ME agar, Becton and Dickinson, Cockeysville, USA).

The resistance to low $\mathrm{pH}$ (3.0) was tested according to Jin et al. (1998). The cells of overnight cultures in $\mathrm{BHI}$ (Becton and Dickinson) were harvested by centrifugation (2 $000 \times g$ for $15 \mathrm{~min}$ ), resuspended in $0.05 \mathrm{M}$ phosphate buffer of pH 3.0 adjusted with $1 \mathrm{~N} \mathrm{HCl}$ and kept at $37^{\circ} \mathrm{C}$ for 1, 2 and $3 \mathrm{~h}$. The cfu were determined on ME agar (Becton and Dickinson). Lactic acid was measured according to Pryce (1969), expressed in $\mathrm{mmol} / \mathrm{l}$ and the lactic acid values were quoted as means \pm standard deviation (SD). Sensitivity/resistance to antimicrobials 
Table 1: The sequences of the primer pairs (F- forward; R- reverse) used for PCR- amplification of the structural genes of enterocins Ent A, P, L 50B, B.

\begin{tabular}{lll}
\hline EntA & F 5' -GGT ACC ACT CAT AGT GC AAA-3' & Aymerich et al., 1996 \\
& R 5'-CCC TGG AAT TGC TCC ACC TAA-3' & \\
\hline EntP & F 5'-GCT ACG CGT TCA TAT GGT AAT-3' & Cintas et al., 1997 \\
& R 5'-TCC TGC AAT ATT CTC TTT AGC-3' & \\
\hline EntL50B & F 5'-ATG GGA GCA ATC GCA AAA TTA-3' & Cintas et al., 1998 \\
& R 5'-TAG CCA TTT TTC AAT TTG ATC-3' & \\
\hline EntB & F 5'-CAA AAT GTA AAA GAA TTA AGA TCG-3' & Casaus et al., 1997 \\
& R 5'-AGA GTA TAC ATT TGC TAA CCC-3' & \\
\hline
\end{tabular}

Table 2: Genotypization, detection of the structural genes for enterocin (Ent) production, lactic acid production (LA) by rabbit meat enterococci

\begin{tabular}{|c|c|c|c|c|c|c|c|}
\hline & \multicolumn{2}{|c|}{ Genotypization } & \multicolumn{4}{|c|}{ Detection of structural genes } & \multirow{2}{*}{$\begin{array}{c}\text { LA production } \\
(\mathrm{mmol} / \mathrm{l})\end{array}$} \\
\hline & E.faecium & E.faecalis & Ent A & Ent $\mathrm{P}$ & Ent B & Ent L50B & \\
\hline M1C & + & - & - & - & + & - & $0.740 \pm 0.091$ \\
\hline M2C & + & - & - & - & + & - & $0.750 \pm 0.065$ \\
\hline M7C & + & - & - & + & + & - & $1.380 \pm 0.011$ \\
\hline M7b & + & - & - & - & - & - & $1.290 \pm 0.042$ \\
\hline $\mathrm{M} 4 \mathrm{C}$ & + & - & - & - & - & - & $1.240 \pm 0.053$ \\
\hline M6C & + & - & - & - & - & - & $1.290 \pm 0.030$ \\
\hline M5A & + & - & - & - & - & - & $1.480 \pm 0.215$ \\
\hline M3b & + & - & - & - & - & - & $1.470 \pm 0.024$ \\
\hline M1b & + & - & - & - & - & - & $1.160 \pm 0.059$ \\
\hline M2A & + & - & - & - & - & - & $1.040 \pm 0.039$ \\
\hline $\mathrm{M} 2 \mathrm{cA}$ & + & - & - & - & - & - & $1.270 \pm 0.128$ \\
\hline $\mathrm{M} 2 \mathrm{cB}$ & + & - & - & - & - & - & $1.200 \pm 0.047$ \\
\hline M3a & + & - & + & - & + & - & $1.430 \pm 0.003$ \\
\hline M4aA & + & - & - & - & - & - & $1.210 \pm 0.074$ \\
\hline M4aB & - & - & - & - & - & - & $1.380 \pm 0.051$ \\
\hline M5aA & - & - & - & - & - & - & $1.260 \pm 0.018$ \\
\hline M5aB & - & - & - & - & - & - & $1.170 \pm 0.062$ \\
\hline $\mathrm{M} 6 \mathrm{~b}$ & - & - & - & - & - & - & $1.140 \pm 0.101$ \\
\hline M7bA & - & - & - & - & - & - & $1.340 \pm 0.181$ \\
\hline M7bB & - & - & - & - & - & - & $1.120 \pm 0.242$ \\
\hline $1 \mathrm{BM}$ & - & - & - & - & - & - & $1.460 \pm 0.254$ \\
\hline $3 \mathrm{AM}$ & - & - & + & - & - & - & $1.570 \pm 0.033$ \\
\hline 4BM1 & + & - & - & - & - & - & $1.470 \pm 0.023$ \\
\hline 4BM2 & - & - & - & - & - & - & $1.540 \pm 0.162$ \\
\hline 5BM1 & + & - & - & - & - & - & $1.200 \pm 0.053$ \\
\hline 5BM2 & - & - & - & - & - & - & $1.700 \pm 0.013$ \\
\hline M1B & + & - & - & - & - & - & $1.460 \pm 0.148$ \\
\hline M2c & - & - & - & - & - & - & $0.880 \pm 0.021$ \\
\hline M1c & + & - & - & - & - & - & $1.710 \pm 0.019$ \\
\hline M5a & - & - & - & - & - & - & $1.720 \pm 0.095$ \\
\hline M6c & + & - & - & - & - & - & $1.050 \pm 0.079$ \\
\hline M3A & - & - & - & - & - & - & $1.310 \pm 0.032$ \\
\hline M4B & + & - & - & - & - & - & $1.56 \pm 0.226$ \\
\hline $\mathrm{M} 2 \mathrm{a}$ & - & - & - & - & - & - & $1.130 \pm 0.098$ \\
\hline
\end{tabular}

was tested by the agar disk diffusion method (NCCLS 2002) on $\mathrm{BHI}$ agar. The following antibiotic disks were used: streptomycin (30 $\mathrm{\mu g}$; LaChema, Czech Republic), neomycin $(5 \mu \mathrm{g})$, gentamicin, ampicillin $(10 \mu \mathrm{g})$, erythromycin $(15 \mu \mathrm{g})$, kanamycin, tetracycline, vancomycin, rifampicin, chloramphenicol (30 $\mu \mathrm{g}$, Becton and Dickinson). After incubation at $37^{\circ} \mathrm{C}$ for $18 \mathrm{~h}$, the strains were classified as resistant or sensitive according to the manufacturers' instructions and the size of the inhibitory zones was expressed in $\mathrm{mm}$.

\section{RESULTS}

The counts of enterococci have ranged from $10^{1}$ to $10^{2}$ $\mathrm{cfu} / \mathrm{g}$. Among 34 isolates, $67.6 \%$ strains have been allotted to the species $E$. faecium and $32.4 \%$ isolate for Ent $\mathrm{A}, \mathrm{B}, \mathrm{P}$ production have been detected in the isolated strains (Table 2). No strain has possessed gene for Ent L50B. Among 34 isolates, in 29 strains (85.3 \%) no s were not allotted to the species yet. The structural genes genes (from the genes tested) have been detected. In $E$. 
Table 3: Resistance of enterococci to antimicrobials ${ }^{\mathrm{a}}$

\begin{tabular}{|c|c|c|c|c|c|c|c|c|c|c|}
\hline Strains & $\operatorname{Rif}^{a}$ & $\mathrm{Kan}^{\mathrm{a}}$ & $\mathrm{Str}^{\mathrm{a}}$ & Ery $^{\mathrm{a}}$ & $\mathrm{Ttc}^{\mathrm{a}}$ & $\mathrm{Gen}^{\mathrm{a}}$ & $\operatorname{Van}^{\mathrm{a}}$ & $\mathrm{Chc}^{\mathrm{a}}$ & $\mathrm{Amp}^{\mathrm{a}}$ & $\mathrm{NeO}^{\mathrm{a}}$ \\
\hline Enterococci & \multicolumn{10}{|c|}{ tested strains/resistant strains } \\
\hline$n=34$ & $34 / 0$ & $34 / 33$ & $34 / 6$ & $34 / 4$ & $34 / 15$ & $34 / 12$ & $34 / 21$ & $34 / 1$ & $34 / 21$ & $34 / 27$ \\
\hline $\mathrm{R}$ in \% & 0.0 & 97.0 & 17.7 & 11.8 & 44.2 & 35.3 & 61.8 & 2.9 & 61.8 & 79.5 \\
\hline
\end{tabular}

${ }^{a}$ Rif- Rifampicin (30 $\left.\mu \mathrm{g}\right)$; Kan- Kanamycin $(30 \mu \mathrm{g})$; Str- Streptomycin $(30 \mu \mathrm{g})$; Erythromycin $(15 \mu \mathrm{g})$; Ttc- Tetracycline $(30$ $\mu \mathrm{g})$; Gen- Gentamicin $(10 \mu \mathrm{g})$; Van- Vancomycin $(30 \mu \mathrm{g})$; Chc- Chloramphenicol (30 $\mu \mathrm{g})$; Amp- Ampicillin (10 $\mu \mathrm{g})$; NeoNeomycin $(5 \mu \mathrm{g})$; R- resistance

Table 4: Antimicrobial activity of enterococci against indicator strains

\begin{tabular}{|c|c|c|c|c|c|c|c|c|c|c|c|c|}
\hline & EA5 & $\begin{array}{c}\mathrm{EF} \\
\text { CCM7420 }\end{array}$ & $\begin{array}{c}\text { LMG } \\
13568\end{array}$ & $\begin{array}{c}\text { LM } \\
\text { CCM4699 }\end{array}$ & $\begin{array}{c}\text { LM } \\
2024\end{array}$ & $\begin{array}{c}\text { LM } \\
7223\end{array}$ & $\begin{array}{c}\text { LM } \\
7562\end{array}$ & SA5 & $\begin{array}{l}\text { S.a. } \\
\text { 3A2 }\end{array}$ & $\begin{array}{l}\text { S.a. } \\
\text { 3A3 }\end{array}$ & $\begin{array}{l}\text { S.a. } \\
5 A 2\end{array}$ & $\begin{array}{l}\text { S.e. ser. } \\
\text { Enteritidis } \\
\text { PT4 }\end{array}$ \\
\hline EF M1C & - & - & - & - & - & - & - & - & - & + & + & - \\
\hline EF M2C & + & + & - & + & - & - & - & - & - & + & + & + \\
\hline EF M7C & - & - & - & + & - & - & - & - & - & - & - & - \\
\hline EF M7b & - & - & - & - & - & - & - & - & + & - & + & - \\
\hline EF M4C & - & - & - & + & - & - & - & - & - & - & - & + \\
\hline EF M6C & + & + & - & $\begin{array}{l}T \\
-\end{array}$ & - & - & - & - & + & - & - & + \\
\hline EF M5a & + & $\begin{array}{l}T \\
+\end{array}$ & - & - & - & - & - & - & $\begin{array}{l}T \\
+\end{array}$ & + & + & $\begin{array}{l}T \\
-\end{array}$ \\
\hline EF M3b & + & - & - & + & - & - & - & - & + & - & - & + \\
\hline $\mathrm{EF} M 1 \mathrm{~b}$ & - & - & - & - & - & - & - & + & - & - & - & - \\
\hline EF M2a & - & - & - & + & - & - & - & $\begin{array}{l}+ \\
-\end{array}$ & - & - & - & - \\
\hline EF M2cA & + & - & - & $\begin{array}{l}+ \\
+\end{array}$ & - & - & - & - & - & - & - & + \\
\hline $\mathrm{EF} M 2 \mathrm{cB}$ & + & - & - & + & - & - & + & - & - & - & - & - \\
\hline EF M3a & - & - & - & - & + & + & + & - & + & + & - & - \\
\hline EF M4aA & - & - & - & - & - & - & - & - & + & + & - & + \\
\hline E.sp.M4aB & + & - & - & - & - & - & - & + & - & - & - & - \\
\hline E.sp.M5aA & - & - & - & - & + & + & + & - & - & + & + & - \\
\hline EF M5aB & - & + & - & - & - & - & - & - & - & - & - & - \\
\hline E.sp. M6b & + & - & - & - & - & - & - & - & - & - & - & - \\
\hline E.sp.M7bA & - & - & - & - & - & - & - & - & - & - & - & + \\
\hline EF M7bB & - & - & - & + & + & + & + & - & - & - & - & $\begin{array}{l}T \\
-\end{array}$ \\
\hline E.sp.1BM & - & - & - & + & - & - & - & - & - & - & - & - \\
\hline E.sp.3AM & - & - & - & + & - & - & - & - & - & - & - & - \\
\hline EF4BM1 & - & - & - & + & - & - & - & - & - & - & - & + \\
\hline E.sp.4BM2 & - & - & - & + & - & - & - & - & - & - & - & - \\
\hline EF5BM1 & - & - & - & - & - & - & - & - & - & - & - & - \\
\hline E.sp.5BM2 & - & - & - & - & - & - & - & - & - & - & - & - \\
\hline EF M1B & - & - & - & - & - & - & - & + & - & + & + & - \\
\hline E.sp.M2c & - & - & - & - & - & - & + & + & - & + & - & - \\
\hline EF M1c & - & - & - & - & - & - & + & - & - & - & - & + \\
\hline E.sp.M5a & - & - & - & + & - & + & + & - & - & + & - & + \\
\hline EF M6c & - & - & - & + & - & - & - & - & - & + & + & - \\
\hline E.sp.M3A & - & - & - & $\begin{array}{l}T \\
-\end{array}$ & - & - & - & - & - & $\begin{array}{l}T \\
+\end{array}$ & + & - \\
\hline EF M4B & - & - & + & + & - & - & - & - & - & - & + & + \\
\hline EF M2A & - & - & + & - & - & - & - & - & - & + & + & - \\
\hline
\end{tabular}

EF- Enterococcus faecium; EA- Enterococcus avium; E.sp.- Enterococcus species; + inhibitory zone around indicator organism, - inactivity; E. avium EA5 (our isolate; piglet); E. faecium CCM 7420 (our isolate; faeces of dog); $S$. aureus SA5, 3A2, 3A3, 5A2 (our isolates, faeces of rabbit); Listeria innocua LMG 13568 (Colection of microorganisms of Gent, Belgium); L. monocytogenes CCM 4699 (Czech Collection of Microorganisms; Brno); L. monocytogenes 2024, 7223,7562 (isolates from food, Veterinary Institute, Olomouc, Czech Republic); Salmonella enterica ser. Enteritidis PT4 (Dr. Šišák; Brno, Czech Republic)

faecium (EF) M1C and M2C only Ent B gene has been detected and in the strain Enterococcus sp. 3AM only Ent A gene has been found (Table 2); E. faecium M7C has possessed Ent $\mathrm{P}$, Ent $\mathrm{B}$ genes. Moreover, in the strain $E$. faecium $\mathrm{M} 3 \mathrm{a}$ the genes for Ent $\mathrm{A}$ and Ent $\mathrm{B}$ production have been detected. On the other hand, the most 


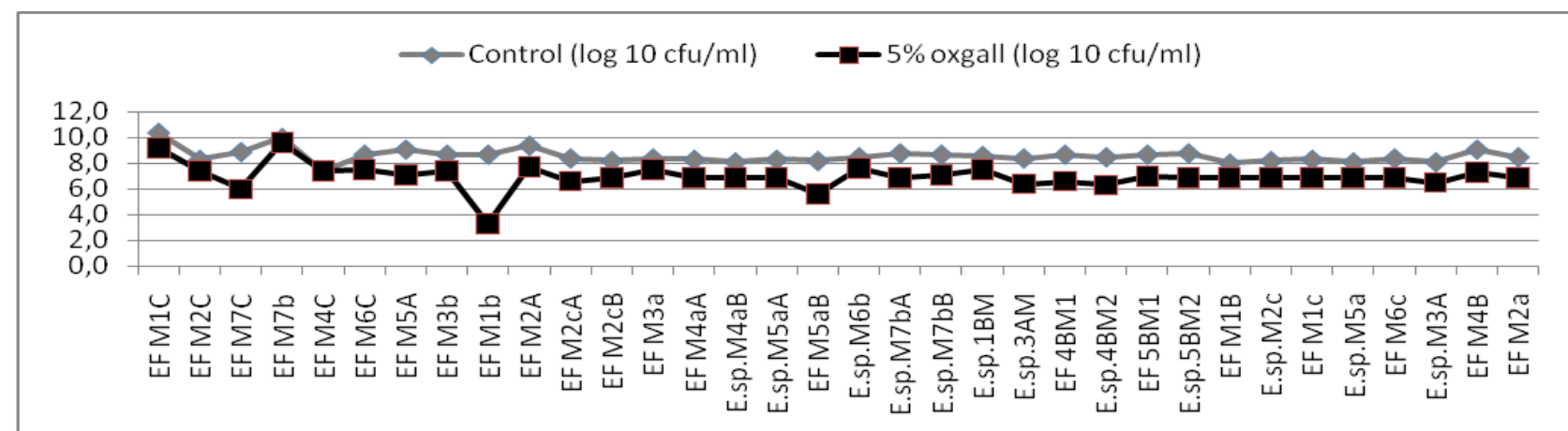

Figure 1: The resistence of bile (5\% oxgall) of tested rabbit meat enterococci (EF-Enterococcus faecium; E.sp.- E. species) expressed in log $10 \mathrm{cfu} / \mathrm{ml}$

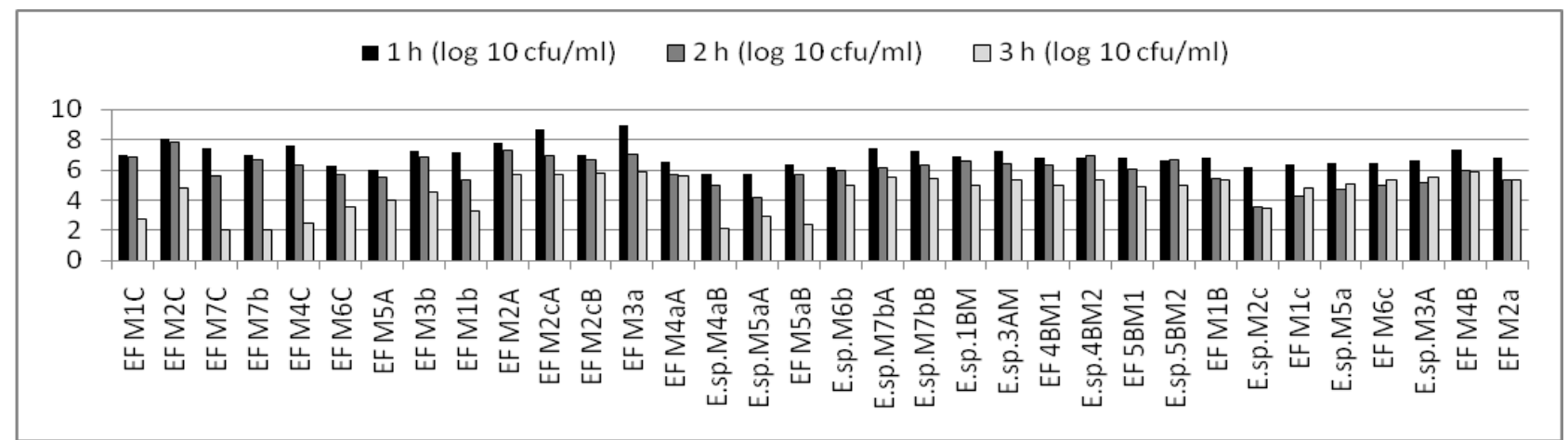

Figure 2: The surviving of tested enterococci incubated at $\mathrm{pH}=3$ for $0,1,2$ and 3 hour

frequently Ent B gene has been found (EF M1C, M2C, M7b, M3a), followed by Ent A gene (EF M3a, E. sp. 3AM) and Ent $\mathrm{P}$ gene (EF M7C).It is interesting, that in spite of the fact that in $85.3 \%$ of It our isolates Ent genes have been not found, the growth of at least one indicator strain has been inhibited by our enterococcal isolates (Table 4); however, E. faecium EF 5BM1 and Enterococcus sp. $5 B M 2$ did not inhibit the growth of the indicator strains (they did not produce bacteriocin against the indicators used. In summary, the growth of 12 indicators (including Listeria monocytogenes, Table 4) has been inhibited by bacteriocin produced by our enterococci. Of 34 isolates, 15 strains $(44.1 \%)$ have showed the antimicrobial activity against L. monocytogenes CCM 4699, 12 strains (35.2\%) against $S$. aureus $3 A 3,10$ strains $(29.4 \%)$ against $S$. aureus $5 \mathrm{~A} 2$ as well as Salmonella enterica serovar Enteritidis PT4. Nine enterococci have inhibited the growth of 2 indicators, 6 strains have showed an inhibitory activity against 3 indicators (Table 4).

On the other hand, only 9 strains among 34 (26.5\%) have shown an inhibitory activity against the principal indicator strain E. avium EA5. However, 6 indicator strains have been inhibited by the substance produced by $E$. faecium $\mathrm{M} 2 \mathrm{C}$ and $\mathrm{M} 3 \mathrm{a}$; those enterococci have possessed Ent $\mathrm{B}$ gene (the strain $\mathrm{EF} \mathrm{M} 2 \mathrm{C}$ ); respectively Ent $\mathrm{A}$, Ent $\mathrm{B}$ genes (the strain EF M3a). Although, $E$. faecium M5a, Enterococcus sp. M5aA and $\mathrm{M} 5 \mathrm{a}$ have shown an inhibitory activity against 5 indicators (Table 4), Ent genes have been not detected there (Table 2). Enterococci have been able to grow in the presence of $5 \%$ oxgall (bile) reaching $10^{3}-10^{9} \mathrm{cfu} / \mathrm{ml}$ in comparison with the control growth $\left(10^{8}-10^{10} \mathrm{cfu} / \mathrm{ml}\right)$ - the strains have grown in oxgallfree broth (Figure 1). It means, they have resisted bile $(38 \%$ to $96 \%)$ as well as low $\mathrm{pH} 3$ - the surviving of enterococci in $\mathrm{pH} 3.0$ have ranged from 2.0 up to 5.9 $\log 10 \mathrm{cfu} / \mathrm{ml}$ for $3.0 \mathrm{~h}$ incubation at $37^{\circ} \mathrm{C}$ (Figure 2).

Lactid acid production of enterococci has ranged from $0.740 \pm 0.091$ to $1.720 \pm 0.095 \mathrm{mmol} / \mathrm{l}$ (Table 2). Enterococci have been sensitive to rifampicin (100\%), streptomycin (82.3\%), chloramphenicol (93.1\%), gentamicin $(64.7 \%)$, erythromycin (88.2\%) and tetracycline $(55.8 \%)$. On the other hand, besides kanamycin resistance $(97.0 \%), 61.8 \%$ strains have been resistant to ampicillin, $79.5 \%$ to neomycin; $61.8 \%$ to vancomycin (Table 3 ).

\section{DISCUSSION}

Among enterococci, E. faecium seems to be the dominant cultivable enterococcal species in rabbits. Prevalence of E. faecium in faeces of rabbits (50\% of 58 isolates) has been also described by Simonová et al. (2005). In general, E. faecium and E. faecalis represent the most frequently occurred species among enterococci from 
different sources (Franz et al., 1999, 2003). Strompfová and Lauková (2007) reported occurrence of these species also in poultry. The species mentioned have also formed predominant colonization of enterococci in piglets; among 55 enterococcal isolates, $67.3 \%$ strains were $E$. faecium (Strompfová and Lauková, 2009) and they have been also reported in healthy dogs (Strompfová et al., 2006). Concerning their occurrence in food matrix, in general, the amount of enterococci in rabbit meat is in accordance with that count reported for meat products by Lauková et al. (2005). Franz et al. (2003) has referred enterococci as probiotic bacteria in different food. The important factor for the evaluation of enterococci as further probiotics is their antimicrobial (bacteriocin) activity against spoilage bacteria. For example, the ability of rabbits enterococci to produce bacteriocin-like substance active against the target of Gram-positive as well as Gram-negative strains was described by Simonová and Lauková (2007).

In addition, strong antilisterial activity of bacteriocins produced by enterococci has also been reported previously in several matrices e.g. cheese, fermented meat products, canine feed, horses and rabbits faeces (Franz et al., 1999; Lauková et al., 2003, 2008a, 2008b; Mareková et al., 2003; Simonová et al., 2005). In our study, some of strains, Enterococcus sp. M5a, E. sp. M5aA, E. faecium M5a have shown an inhibitory activity against 5 of 12 indicator strains; however, they have not possessed enterocin genes. It seems, we can discussed silent genes (Strompfová et al., 2008) or the strains can produce the different bacteriocins as were tested or they inhibited the growth of the indicators due to other antimicrobial agents than bacteriocins (e.g. lactic acid). In this study, Ent L50B gene was not detected in enterococci; oppositelly, in faecal enterococci (from rabbits), Ent L50B was the most frequently detected followed by Ent A gene (Strompfová et al., 2008). Therefore, it is possible that some strains with bacteriocin activity could probably produce new substance.

Commonly, probiotic potential of strains is tested at least by their resistance to bile or low $\mathrm{pH}$. Hyronimus et al. (2000) tested bile tolerance and resistance to acids among spore-forming $\angle A B$ (SFLAB). He concluded that some SFLAB survive in acid conditions $(\mathrm{pH} 2.5-3.0)$ and few SFLAB are weakly tolerant to $0.3 \%$ bile. Our enterococci were found with survival rate at $\mathrm{pH} 3.0$ after 3 $\mathrm{h}$ (in the range $10^{3}-10^{9} \mathrm{cfu} / \mathrm{ml}$ ). Similar results were achieved in enterococci isolated from the gastrointestinal tract of chickens (Strompfová and Lauková 2007) as well as from rabbits' faeces (Simonová, 2006). Rincé et al. (2003) presents results from analysis of the physiological response of E. faecalis ATCC 1943 towards bile salts (susceptibility, homologous tolerance and crossprotections against heterologous stresses) and the identification of genes involved this response. Analysis of E. faecalis susceptibility towards the bile salts has given evidence for an extremely rapid killing effect. Compared to kinetics observed for action of lethal challengesheterologous stresses by heat, ethanol, $\mathrm{NaCl}, \mathrm{H}_{2} \mathrm{O}_{2}$, sodium dodecyl sulfate (SDS), acid $\mathrm{pH}$ and alkaline $\mathrm{pH}$, such as a rapid killing effect was only observed with SDS and suggested that the bile salts probably act by solubilization of membrane components.

LA production by enterococci from rabbit meat was similar to the other enterococci, e.g. from canine feed (Lauková et al., 2008a), horses (Lauková et al., 2008b) and rabbit faeces (Simonová, 2006). Bacteriocin-producing strains with probiotic potential are requested to be absent of antibiotic resistance genes (Klein, 2011). Our strains showed kanamycin (aminoglycoside) resistance but this intrinsic resistance is in enterococci obligatory (usually chromosomally encoded) (Butaye et al., 2001; Kak and Chow, 2002; Klare et al., 2002). Majority of strains were antibiotic sensitive. Lower range of vancomycin resistant enterococci (VRE; $61.8 \%$ ) is curious, but the presence for Van genes was not tested and strains which were selected for further studies are vancomycin sensitive. Acquired type resistance of enterococci to vancomycin has been presented by Leclerq (1997).

VRE in humans are a problem not only because of health, but also because of a possible transmission of VRE from the matrix of domestic animals to humans and/or through the food chain. Acquired type of resistance to vancomycin is conditional on the presence of genes $\operatorname{Van} A$, Van B, Van D, Van E, Van G; Van A gene and Van B are found primarily in bacterial species $E$. faecium and $E$. faecali (Morrison et al., 1997, Méndez-Alvarez et al., 2000). Among enterococcci from piglets, similarly as in our study, more strains were sensitive to tetracycline, chloramphenicol, erythromycin, rifampicin. Moreover, they were also vancomycin sensitive (Strompfová and Lauková, 2009). Simonová (2006) reported resistance of enterococci from rabbit faeces to kanamycin and vankomycin.

\section{CONCLUSION}

Of 34 isolates (mostly allotted to the species E. faecium), 15 strains (44.1\%) have shown the antimicrobial activity against L. monocytogenes CCM 4699, 12 strains (35.2\%) against $S$. aureus $3 A 3,10$ strains $(29.4 \%)$ against $S$. aureus $5 \mathrm{~A} 2$ as well as Salmonella enterica serovar Enteritidis PT4. The structural genes for Ent A, B, P production have been detected in the isolated enterococci. The strain $E$. faecium $\mathrm{M} 3 \mathrm{a}$ has produced bacteriocin with an inhibitory activity against $L$. monocytogenes and $S$. aureus. From the basic point of view, it has been selected for its more detail characterization with the aim for its application possibility e.g. as feed additive. Of course, the following experiments have been requested.

\section{ACKNOWLEDGEMENTS}

This work was supported by the Slovak Scientific Agency VEGA (project 2/0002/11) and by the bilateral project no. SK-HU-0006-08. The authors would like also to thank Mrs. 
M. Bodnárová for her excellent technical assistance in the experiments.

\section{REFERENCES}

Aymerich, T., Holo, H., Havarstein, L.S., Hugas, M. Garriga, M., Nes, I.F. (1996). Biochemical and genetic characterization of enterocin A from Enterococcus faecium, a new antilisterial bacteriocin in the pediocin family of bacteriocins. Applied Environmental Microbiology 62: 1676-1682.

Audisio, M.C., Olivier, G., Apella, M.C. (1999). Antagonostic effect of Enterococcus faecium $\mathbf{J 9 6}$ against human and poultry pathogenic salmonelae species. Journal of Food Protection 62: 751-755.

Baele, M., Vaneechoutte, M., Storms, V., Butaye, P., Devriese, L.A., Verschraegen, G., Gillis, M., Haesebrouck, F. (2000). Application of tDNA-PCR for the identification of enterococci. Journal of Clinical Microbiology 38: 4201-4207.

Bergeys Manual of Systematic Bacteriology (2009). Springer, New York, Bringel, U.S.A., vol. 3. eds. De Vos, P., Garrity, G., Jones, D., Krieg, N.R., Ludwig, W., Rainey, F.A., Schleifer, K.H., Whitman, W.B.

Butaye, P., Devriese, L.A., Haesebrouck, F. (2001). Differences in antibiotic resistance patterns of Enterococcus faecalis and Enterococcus faecium strains isolated from farm and pet animals. Antimicrobial Agents and Chemotherapy 45: 13741378.

Casaus, P., Nilsen, T., Cintas, L.M., Nes, I.F., Hernández, P.E., Holo, H. (1997). Enterocin B, a new bacteriocin from Enterococcus faecium T136 which can act synergistically with enterocin A. Microbiology 143: 2287-2294.

Cintas, L.M., Casaus, P., Havarstein, L.V., Hernández, P.E., Nes, I.F. (1997). Biochemical and genetic characterization of enterocin $\mathrm{P}$, a novel secdependent bacteriocin from Enterococcus faecium P13 with a broad antimicrobial spectrum. Applied Environmental Microbiology 63: 4321-4330.

Cintas, L.M., Casaus, P., Holo, H., Hernández, P.E., Nes, I.F., Havarstein, L.S. (1998). Enterocins L50A and L50B, two novel bacteriocins from Enterococcus faecium L50 are related to staphylococcal haemolysins. Journal of Bacteriology 180: 19881994.

Dalle Zotte, A. (2002). Perception of rabbit meat quality and major factors influencing the rabbit carcass and meat quality. Livestosk Production Science 75:11-32.

Devriese, L.A., Pot, B., Collins, M.D. (1993). Phenotypic identification of the genus Enterococcus and differentiation of phylogenetically distinct enterococcal species and species groups. Journal of Applied Bacteriology 75: 399-408.

Franz, C.M.A.P., Worobo, R.W.W., Quadri, L.E.N., Schillinger, U., Holzapfel, W.H., Vederas, J.C., Stiles, M.E. (1999). Atypical genetic locus associated with constitutive production of enterocin $\mathrm{B}$ by Enterococcus faecium BFE 900. Applied
Environmental Microbiology 65: 2170-2178.

Franz, C.M.A.P., Stiles, M.E., Schleifer, K.H., Holzapfel, W.H. (2003). Enterococci in foods- a conundrum for food safety. International Journal of Food Microbiology 88: 105-122.

Franz, C.M.A.P., Van Belkum, M.J., Holzapfel, W.H., Abriouel, H, Gálvez, A. (2007). Diversity of enterococcal bacteriocins and their grouping in a new classification scheme. FEMS Microbiological Reviews 31: 293-310.

Gilliland, S.E. and Walker, D.K. (1990). Factors to consider when selecting a culture of Lactobacillus acidophilus as a dietary adjunkt to produce a hypocholesterolemic effect in humans. Journal of Diary Science 73: 905-911.

Hyronimus, B., Marrec, C.L., Sassi, A.H., Deschamps, A. (2000). Acid and bile tolerance of sporeforming lactic acid bacteria. International Journal of Food Microbiology 61: 193-197.

Isolauri, E. (2001). Probiotics in humans disease. American Journal of Clinical Nutrition 73: 1142-1146.

Jin, L.Z., Ho, Y.W., Abdullah, N., Ali, M.A., Jalaludin, S. (1998). Effects of adherent Lactobacillus cultures on growth, weight of organs and intestinal microflora and volatile acids in broilers. Animal Feed Science Technology 70: 197-209.

Kak, V. and Chow, J.W. (2002). Acguired antibiotic resistances in enterococci. The enterococci: pathogenesis, molecular biology and antibiotic resistance. Gilmore MS Edition, American Society for Microbiology, Washington DC, pp. 355-383.

Klare, I., Werner, G., Witte, W. (2002). Enterococci. Habitats, infections, virulence factors, resistances to antibiotics. Emergency of Bacterial Pathogens and Control Microbiology 8: 108-122.

Klein, G. (2011). Antibiotic Resistance and Molecular Characterization of Probiotic and Clinical Lactobacillus Strains in Relation to Safety Aspects of Probiotics. Foodborne Pathogens and Disease 8: 267-281.

Lauková, A., Mareková, M., Javorský, P. (1993). Detection and antimicrobial spectrum of a bacteriocinlike substance produced by Enterococcus faecium CCM4231. Letters of Applied Microbiology 16: 257260.

Lauková, A. and Czikková, S. (1998). Inhibition effect of enterocin CCM4231 in the rumen fluid environment. Letters of Applied Microbiology 26: 215-218.

Lauková, A. and Czikková, S. (1999). The use of enterocin CCM 4231 in soy milk to control the growth of Listeria monocytogenes and Staphylococcus aureus. Journal of Applied Microbiology 87: 182-186.

Lauková, A., Turek, P., Mareková, M., Nagy, J. (2003). Use of ent $M$, new variant of ent $P$ to control Listeria innocua in experimentally cantaminated Gombasek sausage. Archive Lebensmittelhygiene 54: 25-48.

Lauková, A., Strompfová, V., Simonová, M., Marciňáková, M. (2005). Quantification and identification of lactic acid bacteria in Slovak meat products. In: Proceedings of Lectures and Posters, 
Hygiena Alimentorum XXVI, Štrbské Pleso, Slovak Republic. pp. 133-136.

Lauková, A., Marciňáková, M., Strompfová, V., Ouwehand, A.C. (2008a). Probiotic potential of enterococci isolated from canine feed. Folia Microbiologica 53: 84-88.

Lauková, A., Simonová, M., Strompfová, V., Štyriak, I., Ouwehand, A., Várady, M. (2008b). Potential of enterococci isolated from horses. Anaerobe 14: 234236.

Levkut, M., Pistl, J., Lauková, A., Revajová V., Herich, R., Ševčíková, Z., Strompfová, V., Szabóová, R., Kokinčáková, T. (2009). Antimicrobial activity of Enterococcus faecium EF 55 against Salmonella enteritidis in chicks. Acta Veterinaria Hungarica 57: 13-24.

Levkut, M., Revajová V., Lauková, A., Ševčíková, Z., Spišáková, V., Faixová, Z., Levkutová, M., Strompfová, V., Pistl, J., Levkut , M. (2011). Leucocytic responses and intestinal mucin dynamics of broilers protected with Enterococcus faecium EF55 and challenged with Salmonella Enteritidis. Research in Veterinary Science,

Leclerq, R. (1997). Enterococci aquire new kinds of resistance. Clinical Infection Diseases 24: S80-S84.

Mareková, M., Lauková, A., De Vuyst, I., Skaugen, M., Nes, I.F. (2003). Partial characterization of bacteriocins produced by environmental strain Enterococcus faecium EK13. Journal of Applied Microbiology 94: 523-530.

Méndez-Alvarez, S., Pérez-Hernández, X., ClaverieMartín, F. (2000). Glycopeptide resistance in enterococci. International Microbiology 3: 71-80.

Morrison, D., Woodford, N., Cookson, B. (1997). Enterococci as emerging pathogens of humans. Journal of Applied Microbiology 83: 89S-99S.

National Committee for Clinical Laboratory Standards (2002). Performance standards for antimicrobial susceptibility testing. Eleventh Informational Supplement. Disk diffusion. M100-S11, NCCLS, Villanova, PA, U.S.A.

Pogány Simonová, M., Lauková, A., Chrastinová, L'., Strompfová, V., Faix, Š., Vasilková, Z., Ondruška, L', Jurčík, R., Rafay, J. (2009). Enterococcus faecium CCM7420, bacteriocin PPB CCM7420 and their effect in the digestive tract of rabbits. Czech Journal of Animal Sciences 54: 376-386.

Pryce, J.D. (1969). Modification of the BarkerSummerson Metod for the determination of lactic acid. Analyst 94: 1151-1152.

Rincé, A., Breton, Y.L., Verneuil, N., Giard, J.C., Hartke, A., Auffray, Y. (2003). Physiological and molecular aspects of bile salt response in Enterococcus faecalis. International Journal of Food Microbiology 88: 207-213.

Simonová, M., Lauková, A., Štyriak, I. (2005). Enterococci from rabbits - potential feed additive. Czech Journal of Animal Sciences 50: 416-421.

Simonová, M. (2006). Probiotic and bacteriocinogenic bacteria and its influence on digestion in rabbits.
Thesis. Institute of Animal Physiology SAS, Košice, Slovak Republic, pp. 89-96.

Simonová, M., Lauková, A. (2007). Bacteriocin aktivity of enterococci from rabbits. Veterinary Research Communications 31: 143-152.

Skalka, B., Pillich, J., Pospíšil, L. (1983). Further observation on Corynebacterium renale as indicator organism in the detection of exfoliation-positive strains Staphylococcus aureus. Zbl Bacteriological Hygiene 256: 168-174.

Strompfová, V., Lauková, A., Mudroňová, D. (2003). Effect of Bacteriocin-Like Substance Produced by Enterococcus faecium EF55 on the Composition of Avian Gastrointestinal Microflora. Acta Veterinaria Brno 72: 559-564.

Strompfová, V., Marciňáková, M., Simonová, M., Gancarčíková, S., Jonecová, Z., Sciranková, L'., Koščová, J., Buleca, V., Čobanová, K., Lauková, A. (2006). Enterococcus faecium EK13-an enterocin A-producing strain with probiotic character and its effect in piglets. Anaerobe 12: 242-248.

Strompfová, V. and Lauková, A. (2007). In vitro study on bacteriocin production of enterococci associated with chickens. Anaerobe 13: 228-237.

Strompfová, V., Lauková, A., Simonová, M., Marciňáková, M. (2008). Occurence of the structural enterocin $A, P, B, L 50 B$ genes in enterococci of different origin. Veterinary Microbiology 132: 293-301.

Strompfová, V. and Lauková, A. (2009). Enterococci from piglets - probiotic properties and

responsiveness to natural antibacterial substances. Folia Microbiologica 54: 538-544.

Szabóová, R., Chrastinová, L'., Lauková, A., Haviarová, M., Simonová, M., Strompfová, V., Faix, Š., Vasilková, Z., Chrenková, M., Plachá, I., Mojto, J., Rafay, J. (2008). Bacteriocin-producing strain Enterococcus faecium CCM 4231 and its use in rabbits. International Journal of Probiotics and Prebiotics 2: 77-82.

Szabóová, R. (2011). Natural substances and its use in rabbit breeding. Thesis. Institute of Animal Physiology SAS, Košice, Slovak Republic, pp. 77-87.

Woodford, N., Egelton, M.C., Morrison, D. (1997). Comparison of PCR with genotypic methods for the speciation of enterococci. Plenum Press New York, U.S.A. 47: 405-409. 